\title{
Teaching
Methods
}

\section{Toward a Philosophy for Capstone Courses in Horticulture}

\author{
Tim Rhodus'and \\ James Hoskins ${ }^{2}$
}

Additional index words. undergraduate curriculum

Summary. Capstone courses generally target undergraduate students who are nearing completion of their studies. They are designed to build on skills acquired in earlier courses and emphasize situations and challenges that exist in the real world. Specific learning goals and course objectives vary across disciplines and institutions, but most capstone courses provide an opportunity for students to demonstrate a range of professional competencies and communication skills. By incorporating computer simulations, case studies, or research projects, students are better able to develop critical-thinking and problem-solving skills, a learning goal

${ }^{2}$ Associate professor, Department of Horticulture and Crop Science and Department of Agricultural Economics, The Ohio State University, Howlette Hall, 2001 Fyffe Ct., Columbus, OH 43210.

${ }^{2}$ Research assistant, Department of Horticulture and Crop Science, The Ohio State University.

Salaries and research support provided by state and federal funds appropriated to the Ohio Agricultural Research and Development Center, The Ohio State University. Manuscript no. 157-94. The cost of publishing this paper was defrayed in part by the payment of page charges. Under postal regulations, this paper therefore must be hereby marked advertisement solely to indicate this fact. frequently adopted following curriculum review. A brief overview of the development, current popularity, and widespread offering of university capstone courses is presented. The goals and organization of 'Quality, Ethics, and the Global Environment," the capstone course in the horticulture major at Ohio State Univ., is compared to other capstone courses.

$\mathrm{T}$ he most appropriate curriculum to nurture an undergraduate student and produce an educated graduate prepared to function as a productive citizen is a perennial issue of debate. The current widespread offering of capstone courses arises from the most recent round of intensive evaluation of college curricula conducted in the early and mid1980s. One widely publicized report, Integrity in the College Curriculum: A Report to the Academic Community (Association of American Colleges, 1983). which was the product of 3 years of study by 18 prominent educators, adopted a tone of alarm using somewhat harsh rhetoric to depict evi dence of decline and devaluation in college curricula and characterized the overall condition as one of disarray and incoherence (Fiske, 1985 ). While the report emphasized the need for a curriculum to inculcate cultural values for the collective civic good, it also focused attention on serious weaknesses within the curriculum and concluded that the quality of American life would be at stake should universities not graduate students able to demonstrate basic competencies in all disciplinary areas at the undergraduate level. Thus, criticisms of a curriculum were not only abstract concerns about deficien ties' in classical education, but carried were a warning that inadequate aca- demic preparation had implications for personal and societal wellbeing.

Educators from diverse disciplines have realized that the challenges of the modern workplace require more than technical expertise. There is a need for graduates who have leadership skills, can work with large teams of workers, and who are able to assimilate and manage a complex flow of information (Durfee, 1994). Because only 20\% of the adult American population has graduated from college (Census of Population, 1990), the form and content of a college curriculum, and the quality of delivery of course content by university professors, play a central role in defining the quality of the leaders of tomorrow.

\section{Bringing breadth to the curriculum}

Integrity in the College Curricu lum identified nine experiences that an undergraduate curriculum should offer students. These nine elements should emerge from a coordinated, integrated curriculum wherein goals of logical thinking and inquiry or the requirement of writing and reading practice are programmatically infused throughout all coursework, regardless of discipline. These nine curriculum elements are as follows.

1) Inquiry: abstract analogical thinking, and critical analysis

2) Literacy: writing, reading, speaking, listening

3) Understanding numerical data

4) Historical consciousness

5) Science

6) Values

7) Art

8) International and multicultural experiences

9) Study in depth

Study in depth, the final point listed above, is an academic experience closely associated with the offering of capstone courses. Norman ( 1985) noted that study in depth should involve an understanding of a discipline's central core of method and theory, its analytical tools, and its complexity. Capstone courses originated, in part, because students nearing completion of undergraduate studies were given insufficient opportunity to integrate and reflect on the parts of study that constituted their major. The usual undergraduate major, the criticism went, 
was poorly planned and deficient in execution because it offered merely an à $1 \mathrm{a}$ carte menu approach to picking and choosing among disparate nonrelated course topics. In this system, overall educational objectives can become lost in a process where students accumulate, or tally up, credit hours toward a graduation requirement.

Without a curriculum requirement mandating otherwise, many students select an academic major early in their college career and, thereafter, venture as infrequently as possible into unrelated disciplinary areas. This is a commonly demonstrated and understandable undergraduate preference. Fulfilling the course requirements of some majors may leave little time for exploration. Moreover, the tendency to not want to leave the major field of study and its related disciplines is not illustrative of the bad instincts of a poor student. Such focused behavior can be observed among some of the better students in a department. Genuinely enthusiastic students often concentrate efforts within a major they find compelling. When students become more involved in their chosen major, usually they have established a comfortable relationship with an academic advisor and other departmental faculty members, and have defined a peer group of other students with common academic interests. A final factor inhibiting curricular exploration may bean upperclassman's reticence to return to an outside major intro course with 100 other less-experienced students, multiple-choice exams administered by teaching assistants, and fewer opportunities for interaction with the professor, thus the student avoids making what could turn out to be, in effect, an educational retreat.

Distribution requirements function within a curriculum to counter the tendency students have toward insularity within a major. It is unusual, however, for distribution requirements to extend into the junior and senior years. David Scott, chancellor of the Univ. of Massachusetts at Amherst and critic of distribution requirements, has likened the process in which freshman and sophomore students fulfill general education requirements to a vaccination: "Now, if you have to take a course in biology and you're an arts major, it's like getting inoculated, so you're immune from doing that again.
We have to break that down" (Henderson, 1994). At some universities, broad educational requirements extending into the final years of college have been instituted. At the Univ. of North Carolina; Chapel Hill, juniors and seniors are required to take perspective courses in natural and social sciences, history, esthetics, and philosophy. A senior capstone seminar is also required (Fiske, 1989). Another way universities have attempted to embody the aforementioned nine educational objectives within a curriculum has been through course redesign. To the extent possible, a science course, for example, requires a writing component or perhaps consideration of its technical subject material in a cultural and historical context.

\section{Defining the capstone course}

The above discussion has described the background of curriculum evaluation and explained motivations behind the popularity of capstone course offerings. The following is a concise general definition of the philosophy of the capstone course.

The capstone course typically is defined as a crowning course or experience coming at the end of a sequence of courses with the specific objective of integrating a body of relatively fragmented knowledge into a unified whole. As a rite of passage, this course provides an experience through which undergraduate students look back over their undergraduate curriculum to make sense of that experience and look forward by building on that experience. In the capstone course, students disengage (i.e., separate) from the undergraduate status and existential condition and reemerge (i.e., incorporate) as graduates prepared to assess critically and act responsibly in civil society. Thus, the capstone course provides the liminal threshold at which students change their status (Durel, 1993)

The above definition suggests two major perspectives in the philosophy of capstone course offerings: the integrative academic experience perspective and the real world preparatory experience perspective. Using the simplest distinction, the former is backward looking, reflective, and integrative in outlook, while the latter encourages students to focus on their immediate postcollege future. A com- monality exists between the two approaches because each seeks to encourage students nearing completion of their major course of study to sum up their experiences. While the goals of the two' perspectives are not mutually exclusive, the distinction is important because the capstone course tends to be defined operationally one way or the other at a given institution.

The goal of a capstone course reflecting the integrative academic experience perspective is to complete the undergraduate experience by providing broad reflective and critical views of the field of concentration (Association of American Colleges, 1990). The mandatory capstone course also serves as a valedictory experience for the senior, requiring the application and integration of skills and knowledge gained through in-depth study in a chosen area of inquiry (Wattendorf, 1993 ). Typical goals and learning objectives of this perspective include the following.

1) A philosophical and historical perspective of the major course of study

2) Inquiry into societal implications of the major

3) A holistic and synthetic overview

4) The big picture

5) An interdisciplinary perspective

6) Mastery of subject material within the chosen major

7) Identification of common bonds between disciplines

8) Identification of the limits of knowledge originating from a given discipline

9) A stretch beyond arbitrary academic boundaries

While capstone courses reflecting the academic integrative perspective are varied in structure, the 'most common form is an intensive senior seminar. It is not unusual for the course to be organized around a specific project (sometimes a group project) or senior thesis. In the capstone course in horticulture at Ohio State Univ., the focus is on examination and reflection on a required industry internship. An important variant within integrative perspective capstone courses, and an alternative to the summation model of coursework within a student's undergraduate major, is the true interdisciplinary capstone course. In these courses, senior students from a variety 
a majors apply their diverse perspectives to the study of a multidisciplinary subject or theme. Examples are as follows: a course on AIDS that explores the biological, psychological, and sociological ramifications of the disease; an interdisciplinary course that studies the interrelation of science and art; a course titled The Nature of Science, which helps students gain an appreciation for science and develop a continuing nonprofessional interest; and, a course that examines physics, chemistry, and biology by discussing five general topics (Souders, 1993).

The goals of capstone courses reflecting the real-world perspective are less lofty than those of the academic integrative perspective, but equally as important. These capstone courses provide students with a culminating experence in preparation for their entry into a career field and engagement with the real world (Magner, 1990). Typical goals and learning objectives of this perspective include the following.

1) Comprehensive examination of knowledge gained from the major area of study in a manner aimed to help students respond positively to their future employers needs and work demands

2) Focusing the direction of students

3) Enhancing students' interpersonal skills

4) Balancing students' high job expectations with need to pay dues

5) Exposure to larger philosophical question of business ethics and civic responsibility

The development of capstone courses that strive to prepare college graduate: better for their first professional employment has been influenced greatly by feedback from prospective employers who have raised concerns about the quality of the college graduates they are employing for jobs (Magner, 1990). Siena College in Loudonville, N. Y., offers a capstone course in software engineering that emphasizes teamwork in which students work in small groups to solve software problems. Pennsylvania State Univ. offers an elective capstone course titled "Workplace Integration Skills for Engineers," which emphasizes setting goals, listening, and effective speaking skills development. At Assumption College in Massachusetts, "The Last Six Weeks" is a course de- signed for seniors to discuss subjects such as job interviewing and office politics in an informal setting. These examples most closely adhere to the elements of the real world preparatory capstone model designed to assist students with the immediate challenge of entering the work force. Other realworld capstone courses treat issues of ethics and civic responsibility in a more traditionally structured academic course. An example is the required capstone study at Eckerd College in St. Petersburg, Fla., in which upperclass students examine issues such as biomedical ethics and pollution (Fiske, 1989). The addition of ethics study has been, according to Magner ( 1990), spurred by critics who say too many graduates lack a sense of ethics and have unreasonably high job expectations; thus, more colleges are designing courses and programs to prepare seniors for the real world.

\section{The capstone course in horticulture at Ohio State University}

The required senior capstone course for students majoring in horticulture is titled "Studies in Quality, Ethics, and the Global Environment." The impetus for the course design dates to a university-wide curriculum review conducted during the late 1980s (United Press International, 1988). The new curriculum adopted by the Dept. of Horticulture emphasizes areas such as writing, data analysis, social diversity, contemporary issues, and a capstone experience in their major. The course is described in the syllabus as follows.

"This course provides students with an in-depth examination of the issues facing contemporary horticultural managers. Students will examine a variety of management principles that affect the ways in which contemporary managers deal with a complex environment, balance ethical considerations with organizational objectives, and deliver a quality product or service. Throughout the course, ethical and global highlights will be presented that complement the topic being discussed. Attention will also focus on organizational characteristics such as historical development, decisionmaking processes, interpersonal communications, and marketing strategies. A term project, which builds on first-hand experience gained through the internship, will enable students to evaluate critically the practices of horticultural firms within the context of contemporary issues."

The course is designed for juniors or seniors who have completed their second writing course requirement, a university-approved internship, and 10 credit hours in horticulture at the 400 level or above. Internships at horticultural firms are typically completed the spring and summer before students begin their senior year. As part of the internship, students gather background information about their firm that covers the historical development of the firm, its organizational structure, decisionmaking procedures, and marketing strategies. In addition, students gather information on management's perception of the key issues facing the firm in the areas of quality, ethics, and the global environment. This information is used to develop a term report about the firm, including a critical analysis of the firm's strengths and weaknesses and recommendations for improvement. Two drafts of the report are reviewed before the final report is assigned a grade.

Students also analyze seven cases that relate to the major topic being presented each week in class. As a supplement to the written case in the textbook, students will see and hear top executives as they share their thoughts and insights on their management practices and their industries. Edited from CNN'S "Pinnacle" program, each 10- to 12-min video segment is directly related to a CNN video case in the text. Discussion of the case also includes student perceptions of the applicability of the case to various horticultural enterprises. The required textbook for the course is a comprehensive management text titled Modem Management (Samuel Certo, 1994). The class meets three times a week for $90 \mathrm{~min}$ of lecture and discussion over a 10-week quarter. Final course grade is determined by internship case report $(20 \%)$, written responses to video cases $(30 \%)$, in-class discussion of video cases $(10 \%)$, and examinations $(40 \%)$.

Specific learning objectives of the course include the following.

1 ) Developing an appreciation of the importance of quality

2) Acquiring knowledge about man- 
agement skills that relate to achieving quality

3) Gaining an appreciation for the arguments for and against businesses assuming social responsibilities

4) Developing an understanding of how ethics can be incorporated into management practices

5) Gaining insight about contemporary issues facing horticultural managers

By combining a review of basic management functions, highlighting their application to horticultural industries, and presenting techniques for solving problems that managers frequently face, the capstone course is positioned midway between the integrative academic and real-world pre paratory perspectives. Overall, students are asked to think business by integrating disciplinary knowledge gained from their horticulture major and the insight and experience from their 10week internship with basic business principles.

\section{Conclusion}

Horticulture graduates face unique challenges when they first enter the job market. In most cases, they compete directly with technical school graduates for advancement and increased responsibilities. Their greatest initial challenge relates to hands-on or practical skills. Unless they are able to demonstrate this competence, their chances for successful employment are slim, at best. As they mature, they will probably find more and more opportunities to apply what they have learned in college, but probably not under the controlled environment that one usually experiences in college laboratories and lectures. Eventually, our graduates exhaust their cookbook recommendations and solutions faithfully recorded in notebooks, long since dogeared from frequent searching and use, and begin to develop their own expertise. In essence, the undergraduate curriculum must impart the techni- cal skills students need to compete successfully as they begin their careers and expose them to diverse areas of study that will be invaluable as they advance and assume significant leadership roles. The capstone course figures importantly in achieving this goal.

\section{Literature Cited}

Association of American Colleges. 1985. Integrity in the college curriculum: A report to the academic community. Assn. of Amer. Colleges, Washington, D.C.

Durel, R.J. 1993. The capstone course: A rite of passage, Teaching Sociol. 21( July) :223-225.

Certo, S.C. 1994. Modern management: Diversity, quality, ethics, and the global environment. 6th ed. Allyn and Bacon, Needham Heights, Mass.

Durfee, W.K. 1994. Engineering education gets real. TechnoL Rev. 97(2).

Fiske, E.B. 1985. Three-year survey finds college curriculums in U.S. in 'disarray.' New York Times, 11 Feb.

Fide, E.B. 1989. Education; lessons. New York Times, 20 Sept.

Henderson, K. 1994. New chancellor plans to build bridges between campuses and private industry. Christian Sci. Monitor, 10 Jan.

Magner, D.K. 1990. Many colleges design coursesandprogramstoprepare seniors to live in the 'real world.' Chronicle Higher Education, 21 Mar.

Norman, C. 1985. College curricula in disarray, study says; Association of American Colleges. Science, 1 Mar.

Souders, J. C. 1993. Powers of ten: A model ofan interdisciplinary capstone course for thebasic sciences. J. College Sci. Teaching, March/April

United Press International. 1988. A new OSU curriculum is approved. Reg. News, 11 June.

U.S. Bureau of the Census. 1990. Census of population, social and economic characteristics. U.S. Bur. Census, Wash., D.C.

Wattendorf, J.M. 1993. The sociology capstone course in a professional school. Teaching Sociol. 21(July):229-232. 